\title{
PENGARUH MODEL PEMBELAJARAN PROBLEM POSING BERBANTUAN SCAFFOLDING TERHADAP KEMAMPUAN KOMUNIKASI MATEMATIS SISWA KELAS X SMA NEGERI 1 LUBUK PAKAM
}

\author{
${ }^{1}$ Echo Genesis Perangin-Angin, ${ }^{2}$ Humuntal Banjarnahor \\ ${ }^{1}$ Fakultas Matematika dan Ilmu Pengetahuan Alam, Universitas Negeri Medan \\ ${ }^{2}$ Dosen Fakultas Matematika dan Ilmu Pengetahuan Alam, Universitas Negeri Medan \\ Email: echo.genesis@yahoo.co.id
}

\begin{abstract}
ABSTRAK
Penelitian ini bertujuan untuk mengetahui apakah terdapat pengaruh model pembelajaran problem posing berbantuan scaffolding terhadap kemampuan komunikasi matematis siswa dan mengetahui bagaimanakah peningkatan kemampuan komunikasi matematis siswa kelas. Populasi dalam penelitian ini adalah seluruh kelas X SMA yang terdiri dari 10 kelas dan jumlah keseluruhan siswa kelas $X$ sebanyak 407 orang. Sedangkan yang menjadi sampel dalam penelitian ini dipilih dua kelas yang menjadi sampel penelitian secara random sampling, didapat kelas X MIA 6 dan X MIA 5 yang masing-masing berjumlah 40 orang. Kelas experiment yaitu kelas X MIA 6 menggunakan Model Pembelajaran Problem Posing Berbantuan Scaffolding dan kelas kontrol yaitu kelas X MIA 5 menggunakan Model Pembelajaran Konvensional. Jenis penelitian ini adalah quasi experiment. Sebagai alat pengumpul data digunakan data pretest dan postest dalam bentuk test isian pada materi teorema phytagoras untuk pretest dan materi aturan sinus dan cosinus untuk postest, dimana masing-masing soal berjumlah 9 soal yang sudah divalidkan. Selanjutnya untuk alat pengumpul data yang lain digunakan juga data N-Gain, data ini diperlukan untuk mengetahui bagaimana peningkatan kemampuan komunikasi matematis siswa pada kelas experiment dan kelas kontrol. Sebelum dilakukan uji normalitas dan homogenitas sebagai syarat uji hipotesis, terlebih dahulu dilakukan uji kesamaan dua rata-rata data pretest. Hasil penelitian kemampuan komunikasi matematis siswa yang diajar menggunakan model pembelajaran problem posing berbantuan scaffolding lebih tinggi daripada kemampuan komunikasi matematis siswa yang diajar tanpa menggunakan model pembelajaran problem posing berbantuan scaffolding dengan kata lain "terdapat pengaruh model pembelajaran problem posing berbantuan scaffolding terhadap kemampuan komunikasi matematis siswa".

Pada data N-Gain untuk mengetahui bagaimana peningkatan kemampuan komunikasi matematis siswa pada kelas experiment dan kelas kontrol diperoleh hasil bahwa jumlah siswa pada kelas experiment yang memiliki $\mathrm{N}$-Gain tinggi sebanyak 10 siswa ataupun $25 \%$, jumlah siswa pada kelas experiment yang memiliki $N$-Gain sedang sebanyak 23 siswa ataupun 57,5\%, dan jumlah siswa pada kelas experiment yang memiliki $N$-Gain rendah sebanyak 7 siswa 17,5\%, sedangkan jumlah siswa pada kelas kontrol yang memiliki $N$-Gain tinggi sebanyak 6 siswa ataupun 15\%, jumlah siswa pada kelas kontrol yang memiliki $\mathrm{N}$-Gain sedang sebanyak 13 siswa ataupun 32,5\%, dan jumlah siswa pada kelas kontrol yang memiliki $N$-Gain rendah sebanyak 21 siswa 52,5\%, dapat disimpulkan bahwa peningkatan kemampuan komunikasi matematis kelas experiment lebih tinggi daripada kelas kontrol.
\end{abstract}

Kata Kunci : Quasi Experiment, Problem Posing, Scaffolding

Echo Genesis Perangin-Angin, Humuntal Banjarnahor. Pengaruh Model Pembelajaran Problem Posing Berbantuan Scaffolding Terhadap Kemampuan Komunikasi Matematis Siswa Kelas X SMA Negeri 1 Lubuk Pakam. Jurnal Inspiratif, Vol. 3 No. 1 April 2017 


\begin{abstract}
This study aims to determine whether there is an effect of learning model of problem posing scaffolding assisted to the mathematical communication ability of grade X $S$ and know how improvement of mathematical communication ability students. The population in this study is the entire which consists of 10 classes and the total number of students of class $X$ as much as 407 people. While the sample in this study selected two classes that become random sampling samples, obtained class X MIA 6 and X MIA 5, each amounting to 40 people. The experiment class is X Class MIA 6 using model of Problem Posing Scaffolding Assisted and control class ie class X MIA 5 using Conventional Learning Model. This type of research is quasi experiment. As a data collection tool, we use pretest and postest data in the form of content test on phytagoras theorem material for pretest and sine and cosine rules for posttest, where each problem is 9 validated questions. Furthermore, for other data collection tools used also N-Gain data, this data is needed to know how to improve students' mathematical communication ability in experiment class and control class. Prior to the normality and homogeneity test as a condition of hypothesis testing, firstly tested the similarity of two average pretest data. Research result can be concluded that the mathematical communication ability of grade $X$ students which is taught using learning model of scaled-assisted problem posing is higher than mathematical communication ability of grade X students which is taught without using problem learning model with scaffolding assisted by word Other "there is the influence of learning model of problem posing scaffolding assisted to the mathematical communication ability ". In N-Gain data to find out how to improve students' mathematical communication ability in experiment and control class, it is found that the number of students in experiment class with high $\mathrm{N}$-Gain is 10 students or $25 \%$, the number of students in the experiment class that has $\mathrm{N}$-Gain 23 students or $57.5 \%$, and the number of students in the experimental class with low $N$-Gain were 7 students $17.5 \%$, while the number of students in the control class with N-Gain was 6 students or $15 \%$ Students in the control class who had N-Gain were 13 students or $32.5 \%$, and the number of students in the control class who had low N-Gain was 21 students $52.5 \%$, it can be concluded that the improvement of mathematical communication ability of higher experiment class Than the control class.
\end{abstract}

Keywords : Quasi Experiment, Problem Posing, Scaffolding.

\section{PENDAHULUAN}

Pendidikan merupakan hal penting untuk membekali peserta didik menghadapi masa depan. Di Indonesia pendidikan diatur dalam Undang-undang tersendiri mengenai Sistem Pendidikan Nasional (Sisdiknas), seperti yang tercantum dalam Undang-undang Sisdiknas tahun 2003 bahwa:

Pendidikan nasional berfungsi mengembangkan kemampuan dan membentuk watak serta peradaban bangsa yang bermartabat dalam rangka mencerdaskan kehidupan bangsa, bertujuan untuk berkembangnya potensi peserta didik agar menjadi manusia yang beriman dan bertaqwa kepada Tuhan
Yang Maha Esa, berakhlaq mulia, sehat berilmu, kreatif, mandiri, dan menjadi warga negara yang demokratis serta bertanggung jawab.

Pendidikan sebagai sebuah aktivitas tidak lepas dari fungsi dan tujuan. Fungsi utama pendidikan mengembangkan kemampuan dan membentuk watak, kepribadian serta peradaban yang bermartabat dalam hidup dan kehidupan atau dengan kata lain pendidikan berfungsi memanusiakan manusia agar menjadi manusia yang benar sesuai dengan norma yang dijadikan landasannya (Kadir, 2012:81).

Menurut Sagala (2009:4)“ pendidikan itu ialah usaha sadar yang

Echo Genesis Perangin-Angin, Humuntal Banjarnahor. Pengaruh Model Pembelajaran Problem Posing Berbantuan Scaffolding Terhadap Kemampuan Komunikasi Matematis Siswa Kelas X SMA Negeri 1 Lubuk Pakam. Jurnal Inspiratif, Vol. 3 No. 1 April 2017 
dilakukan oleh keluarga, masyarakat dan pemerintah melalui kegiatan bimbingan, pengajaran, dan atau latihan yang berlangsung di sekolah dan di luar sekolah. Usaha sadar tersebut dilakukan dalam bentuk pembelajaran". Dilihat dari definisi di atas, pembelajaran merupakan upaya yang dilakukan untuk menentukan tercapainya tujuan pendidikan.

Matematika merupakan salah satu ilmu yang sangat penting dalam kehidupan. Banyak hal yang ditemui di dalam kehidupan kita sehari-hari selalu berhubungan dengan matematika. Pendidikan matematika merupakan pondasi yang sangat menentukan dalam membentuk sikap, kecerdasan, dan kepribadian.

Matematika merupakan ilmu universal yang mendasari perkembangan teknologi modern dan penting dalam berbagai disiplin ilmu serta mampu mengembangkan daya pikir manusia. Bagi dunia keilmuan, matematika memiliki peran sebaagi bahasa simbolik yang memungkinkan terwujudnya komunikasi secara cermat dan tepat. Dapat dikatakan bahwa perkembangan pesat dibidang teknologi informasi dan komunikasi dewasa ini dilandasi oleh perkembangan matematika. Oleh karena itu, mata pelajaran matematika perlu diajarkan disetiap jenjang pendidikan untuk membekali siswa dengan mengembangkan kemampuan menggunakan bahasa matematika dalam mengkomunikasikan ide atau gagasan matematika untuk memperjelas suatu keadaan atau masalah.

Namun, matematika masih menjadi pelajaran yang sulit di mata siswa. Berdasarkan hasil wawancara peneliti dengan salah satu guru bidang studi matematika di SMA NEGERI 1 Lubuk Pakam yaitu Bapak Dekson Girsang, S.Pd pada tanggal 9 Januari 2017 saat ditanyakan tentang bagaimana partisipasi siswa didalam kegiatan pembelajaran yang berlangsung di dalam kelas terhadap mata pelajaran Matematika, Bapak Dekson menjawab:
Bagi siswa yang ada di kelas $\mathrm{X}$ baik itu jurusan MIA maupun IS masih mengalami masalah. Partisipasi siswa yang ada masih rendah karena mereka masih menganggap bahwa matematika adalah mata pelajaran yang sulit dan membosankan. Walaupun tidak seluruhnya siswa tidak menyukai pelajaran matematika, tetapi kebanyakan dari siswa masih menganggap bahwa matematika adalah mata pelajaran yang sulit.

Menurut Abdurrahman (2012:202) "banyak orang yang memandang matematika sebagai bidang studi yang paling sulit". Hal senada juga disampaikan oleh Kresma (2014:153) "matematika telah diberi label negatif di kalangan siswa, yaitu sebagai pelajaran yang sulit, menakutkan, dan membosankan. Karakteristik matematika yang abstrak dan sistematis menjadi salah satu alasan sulitnya siswa mempelajari matematika serta menjadikannya paling ditakuti oleh siswa".

Selama ini, proses pembelajaran matematika pada materi pokok Trigonometri disajikan kurang menarik siswa dalam belajar, dominasi guru juga masih tinggi dan tidak melibatkan siswa secara aktif, sehingga berakibat banyak siswa mengalami kesulitan untuk memahami materi dan akibatnya mereka memiliki prestasi belajar yang rendah. Trigonometri sebagai salah satu kompetensi yang dikeluhkan siswa karena banyaknya rumus yang tidak saja harus dihafal tetapi juga memerlukan pemahaman tinggi dalam penerapannya.

Hal ini dikuatkan oleh hasil wawancara peneliti dengan salah satu guru bidang studi matematika di SMA Negeri 1 Lubuk Pakam yaitu Bapak Dekson Girsang, S.Pd pada tanggal 9 Januari 2017 saat ditanyakan tentangletak kesulitan siswa dalam memahami materi trigonometri dari pengalaman beliau di tahun sebelumnya saat mengajarkan siswa di kelas, Bapak Dekson menjawab:

Untuk beberapa anak karena dia siswanya tidak visual sehingga untuk perbandingan

Echo Genesis Perangin-Angin, Humuntal Banjarnahor. Pengaruh Model Pembelajaran Problem Posing Berbantuan Scaffolding Terhadap Kemampuan Komunikasi Matematis Siswa Kelas X SMA Negeri 1 Lubuk Pakam. Jurnal Inspiratif, Vol. 3 No. 1 April 2017 
trigonometri saja untuk menetapkan mana sisi miring, depan dan samping untuk menandai itu saja mereka masih bermasalah. Itu adalah hal yang mendasar.

Matematika memiliki keterkaitan tiap konsep terjalin erat dan rapi, sehingga pemahaman dalam suatu konsep akan sangat mendukung pemahaman terhadap konsep lainnya. Contohya penguasaan konsep trigonometri di kelas X (sepuluh) akan sangat mendukung penguasaan konsep materi lainnya di kelas XI (sebelas), karena banyak materi yang saling terjalin dengan konsep trigonometri seperti halnya dengan limit, differensial, lingkaran, dan yang lainnya. Serta akan berlanjut ke materi di kelas XII (dua belas).

Matematika perlu diajarkan kepada siswa karena, (1) selalu digunakan dalam segala segi kehidupan, (2) semua bidang studi memerlukan keterampilan matematika yang sesuai, (3) merupakan sarana komunikasi yang kuat, singkat dan jelas, (4) dapat digunakan untuk menyajikan informasi dalam berbagai cara, (5) meningkatkan kemampuan berpikir logis, ketelitian, dan kesadaran keruangan, dan (6) memberi kepuasan terhadap usaha memecahkan masalah yang menantang (Abdurrahman, 2012:204).

Dari pernyataan Abdurrahman (2012:204) yang ketiga "matematika merupakan sarana komunikasi yang kuat, singkat dan jelas", sehingga matematika tidak hanya sekedar alat bantu berfikir, alat untuk menentukan pola, tetapi matematika juga sebagai wahana komunikasi antar siswa dan komunikasi antara guru dengan siswa. Menurut Sumiati dan Asra (2016:67) "komunikasi berarti berpartisipasi memberitahukan dan menjadikan milik bersama, sehingga diperlukan keaktifan dari siswa agar tercapai tujuan komunikasi tersebut".

Komunikasi merupakan bagian yang sangat penting pada matematika dan pendidikan matematika. Bagi guru, komunikasi dalam matematika menolong guru memahami kemampuan siswanya, seperti yang diungkapkan oleh Sumiati dan Asra (2016:64) bahwa "guru seharusnya mengenali siswanya dengan baik melalui interaksi dan komunikasi yang lebih baik sehingga siswa dapat mengembangkan kemampuannya". Sedangkan menurut Fadilah (2015:117127) bagi siswa matematika yaitu:

Sebagai alat komunikasi (mathematics as communication) yang merupakan pengembangan bahasa dan simbol untuk mengkomunikasikan ide matematika, sehingga siswa dapat: (1) mengungkapkan dan menjelaskan pemikiran mereka tentang ide matematika dan hubungannya, (2) merumuskan definisi matematika dan membuat generalisasi yang diperoleh melalui investigasi (penemuan), (3) mengungkapkan ide matematika secara lisan dan tulisan, (4) membaca wacana matematika dengan pemahaman, (5) menjelaskan dan mengajukan secara memperluas pertanyaan terhadap matematika yang telah dipelajarinya, dan (6) menghargai keindahan dan kekuatan notasi matematika, serta peranannya dalam mengembangkan ide/gagasan matematika.

Dapat disimpulkan komunikasi dalam matematika bagi siswa adalah sarana untuk bertukar pemikiran dan informasi yang mereka miliki. Masalah yang sering timbul adalah respon yang diberikan siswa atas informasi yang diterimanya tidak sesuai dengan apa yang diharapkan. Hal ini mungkin terjadi karena karakteristik dan matematika yang sarat dengan istilah dan simbol, sehingga tidak jarang ada siswa yang mampu menyelesaikan soal matematika dengan baik, tetapi tidak mengerti apa yang sedang dikerjakannya.

Salah satu isu penting dalam pembelajaran matematika saat ini adalah pentingnya pengembangan kemampuan komunikasi matematis siswa. Pengembangan komunikasi juga menjadi salah satu tujuan pembelajaran martematika dan menjadi salah satu standar kompetensi kelulusan dalam bidang matematika. Karena belajar matematika merupakan proses sosial

Echo Genesis Perangin-Angin, Humuntal Banjarnahor. Pengaruh Model Pembelajaran Problem Posing Berbantuan Scaffolding Terhadap Kemampuan Komunikasi Matematis Siswa Kelas X SMA Negeri 1 Lubuk Pakam. Jurnal Inspiratif, Vol. 3 No. 1 April 2017 
dimana mereka harus berinteraksi, bekerjasama, dan berkomunikasi antara siswa yang satu dengan siswa lainnya serta dengan gurunya (Rina, 2015:2).

Sedikitnya ada dua alasan penting yang menjadikan komunikasi dalam pembelajaran matematika perlu menjadi fokus perhatian, yaitu (1) matematika sebagai bahasa, matematika bukan hanya sebagai alat bantu berpikir yang membantu kita menemukan pola, menyelesaikan masalah, dan menarik kesimpulan, tetapi matematika juga sebagai alat bantu yang baik untuk mengkomunikasikan berbagai ide sehingga jelas, tepat, dan ringkas, dan (2) pembelajaran matematika merupakan aktivitas sosial, baik antara guru dan siswa maupun antara siswa itu sendiri (Maulina, 2013:5).

Lebih lanjut Maulina (2013:5) menyatakan bahwa "kemampuan komunikasi matematis membantu siswa dalam meningkatkan pemahaman, menetapkan pemahaman bersama, memberdayakan siswa sebagai pembelajar, menyediakan lingkungan belajar yang nyaman, dan membantu guru dalam mengidentifikasi pemahaman dan miskonsepsi dari siswa sehingga dapat mencari cara untuk mengarahkan siswa".

Salah satu model komunikasi matematis yang dikembangkan adalah komunikasi model Cai, Lane, dan Jacobsin (dalam Fachrurazi, 2011:81) meliputi: (1) Menulis matematis. Pada kemampuan ini siswa dituntut untuk dapat menuliskan penjelasan dari jawaban permasalahannya secara matematis, masuk akal, jelas serta tersusun secara logis dan sistematis. (2) Menggambar secara matematis. Pada kemampuan ini, siswa dituntut untuk dapat melukiskan gambar, diagram, dan tabel secara lengkap dan benar. (3) Ekpresi matematis. Pada kemampuan ini, siswa diharapkan mampu untuk memodelkan permasalahan matematis secara benar, kemudian melakukan perhitungan atau mendapatkan solusi secara lengkap dan benar.

Dari hasil tes diagnostik yang dilakukan oleh peneliti di SMA NEGERI 1 Lubuk Pakam juga menunjukkan hal yang serupa, masih rendahnya kemampuan komunikasi matematis siswa yang ditunjukkan dari hasil jawaban siswa di kelas X MIA 6. Dari data diperoleh bahwa hasil tes diagnostik yang diberikan kepada siswa kelas X MIA 6 masih jauh dari harapan. Soal yang diberikan berjumlah 3 (tiga) yang masing-masing sesuai dengan aspek-aspek komunikasi matematis, dari 39 orang jumlah siswa kelas X MIA 6 belum ada yang mampu menjawab soal tes diagnostik dengan tepat dan benar secara keseluruhan. Adapun contoh jawaban salah satu siswa kelas X MIA 6 dapat dilihat dari tabel berikut.

Echo Genesis Perangin-Angin, Humuntal Banjarnahor. Pengaruh Model Pembelajaran Problem Posing Berbantuan Scaffolding Terhadap Kemampuan Komunikasi Matematis Siswa Kelas X SMA Negeri 1 Lubuk Pakam. Jurnal Inspiratif, Vol. 3 No. 1 April 2017 


\section{Tabel 1. Data Kesalahan Hasil Pekerjaan Siswa}

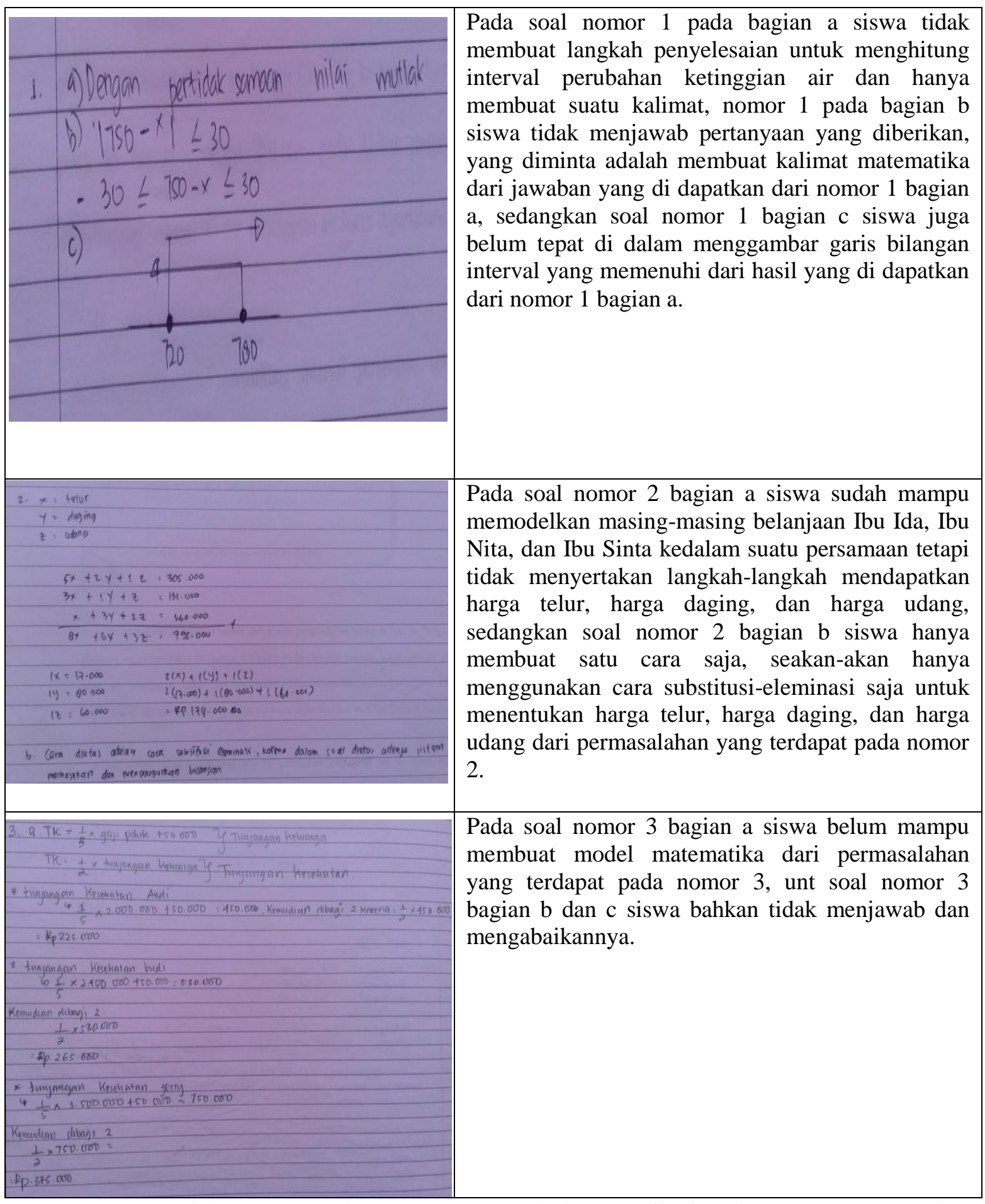

Rendahnya kemampuan

komunikasi matematis siswa disebabkan karena guru jarang sekali mengikutsertakan siswa dalam aktivitas dan proses pembelajaran melainkan hanya menerima informasi tanpa mempertanyakan mengapa dan untuk apa mereka mempelajari matematika. Siswa

belum diberi kesempatan untuk mengkomunikasikan ide mereka. Sehingga tidak jarang muncul anggapan bahwa matematika merupakan mata pelajaran yang sulit dan membingungkan.

Berdasarkan hasil wawancara peneliti dengan salah satu guru bidang studi matematika di SMA Negeri 1 Lubuk

Echo Genesis Perangin-Angin, Humuntal Banjarnahor. Pengaruh Model Pembelajaran Problem Posing Berbantuan Scaffolding Terhadap Kemampuan Komunikasi Matematis Siswa Kelas X SMA Negeri 1 Lubuk Pakam. Jurnal Inspiratif, Vol. 3 No. 1 April 2017 
Pakam yaitu Bapak Dekson Girsang, S.Pd menyatakan bahwa:

Model pembelajaran yang saya terapkan sehari-hari biasanya di dalam kelas yaitu model pembelajaran konvensional. Saya menerangkan secara langsung kepada siswa mengenai materi yang akan saya sampaikan. Hanya untuk beberapa materi saya menggunakan media seperti alat peraga untuk memudahkan saya dalam menyampaikan materi tersebut.

\section{Menurut Kresma (2014:155) "model pembelajaran konvensional adalah model pembelajaran tradisional atau disebut juga dengan metode ceramah, karena sejak dulu metode ini telah dipergunakan sebagai alat komunikasi lisan antara guru dengan anak didik dalam proses belajar dan pembelajaran". Dalam pembelajaran model konvensional ditandai dengan ceramah yang diiringi dengan penjelasan, serta pemberian tugas} dan latihan.

Peningkatan kemampuan komunikasi matematis siswa dapat dilakukan dengan mengoptimalkan model pembelajaran yang diterapkan oleh guru dikelas. Guru hendaknya memakai model pembelajaran yang dapat membangun komunikasi banyak arah antara guru dengan siswa, maupun siswa dengan siswa. Dengan penerapan model pembelajaran tertentu dalam kegiatan pembelajaran, guru diharapkan dapat menggali ide-ide yang dimiliki siswa dalam kegiatan pembelajaran. Sehubungan dengan hal tersebut, dalam usaha meningkatkan kemampuan komunikasi matematis siswa guru dapat menggunakan model pembelajaran problem posing berbantuan scaffolding sebagai salah satu alternatif model pembelajaran yang diterapkan dikelas.

Problem posing merupakan istilah dalam bahasa Ingris yaitu berarti pengajuan atau pembuatan soal. Pembelajaran dengan model problem posing menuntut siswa agar mampu mengajukan suatu soal berdasarkan situasi yang diberikan melalui kegiatan diskusi kelompok. Dalam pembelajaran problem posing, siswa tidak hanya diminta membuat soal tetapi mereka juga harus mampu menjelaskan soal yang mereka susun kepada teman-temannya melalui kegiatan presentasi di depan kelas.Menurut Rina (2015:5) bahwa "problem posing adalah aktivitas yang meliputi merumuskan soal-soal dari halhal yang diketahui dan menciptakan soalsoal baru dengan cara memodifikasi kondisi-kondisi dari masalah-masalah yang diketahui tersebut serta menyelesaikannya".

Dalam pembelajaran problem posing di kelas, peran guru adalah sebagai fasilitator dalam membantu dan membimbing siswa mengkomunikasikan ide matematika mereka. Bantuan yang diberikan pada tahap awal pembelajaran kemudian mengurangi bantuan tersebut sampai siswa mendapat kesempatan belajar secara tanggung jawab. Bantuan ini dinamakan scaffolding.

Scaffolding merupakan bantuan yang diberikan oleh orang dewasa, dalam hal ini adalah orang yang lebih mampu, kepada anak yang akhirnya berkurang sampai anak tersebut dapat belajar secara tanggung jawab (Anghileri, 2006:33). Scaffolding yang diberikan dalam bentuk pertanyaan, dorongan, maupun peringatan yang dapat mengarahkam siswa agar mampu mengkomunikasikan ide matematikanya dalam membuat soal berdasarkan situasi yang diberikan serta mencari solusi dari permasalahan yang dihadapi.

Dari penelitian yang dilakukan oleh beberapa peneliti yang relevan dengan penelitian ini, terlihat bahwa secara keseluruhan model pembelajaran problem posing sangat berpengaruh terhadap kemampuan komunikasi matematis siswa. Hal ini dapat dilihat seperti salah satucontoh penelitian Fani (2012) berjudul "Pengaruh Pembelajaran dengan Pendekatan Problem Posing terhadap Kemampuan Komunikasi Matematis Siswa SMP". Hasil penelitian menunjukkan bahwa peningkatan kemampuan komunikasi matematis siswa yang mendapatkan pembelajaran dengan

Echo Genesis Perangin-Angin, Humuntal Banjarnahor. Pengaruh Model Pembelajaran Problem Posing Berbantuan Scaffolding Terhadap Kemampuan Komunikasi Matematis Siswa Kelas X SMA Negeri 1 Lubuk Pakam. Jurnal Inspiratif, Vol. 3 No. 1 April 2017 
pendekatan problem posing lebih baik daripada siswa yang mendapatkan pembelajaran dengan pendekatan ekspositori.

\section{Metode Penelitian}

Penelitian ini merupakan penelitian eksperimen semu (quasi experiment) karena kondisi siswa tidak dapat dikontrol sepenuhnya seperti : persiapan siswa sebelum proses pembelajaran berlangsung, les tambahan di luar jam sekolah, hubungan siswa dengan orang tua, hubungan siswa dengan lingkungannya, dan lain sebagainya.

Lokasi penelitian ini dilakukan di SMA Negeri 1 Lubuk Pakam yang berlokasi di Jln. Dr.Wahidin No.1, Lubuk Pakam. Waktu pelaksanaan penelitian dilakukan pada semester genap pada Tahun Ajaran 2016/2017. Populasi dalam penelitian ini adalah seluruh siswa kelas X SMA Negeri 1 Lubuk Pakam yang berjumlah 407 siswa yang tersebar dalam 10 kelas, dimana jurusan MIA ada 6 kelas dan jurusan IS ada 4 kelas. Dari 10 kelas X di SMA Negeri 1 Lubuk Pakam dilakukan pengambilan secara random sampling untuk memperoleh 2 kelas untuk dijadikan kelas eksperimen dan kelas kontrol. Dari hasil pengambilan secara random sampling, diperoleh kelas X MIA 6 sebagai kelas experiment yang menggunakan pembelajaran problem posing berbantuan scaffolding dan kelas $\mathrm{X}$ MIA 5 sebagai kelas kontrol yang menggunakan

konvensional. pembelajaran

Desain penelitian yang digunakan dalam penelitian ini adalah Pretest dan Posttest. Instrumen yang digunakan dalam penelitian ini adalah tes kemampuan komunikasi matematis siswa. Analisis data dalam penelitian ini terdiri dari pengujian normalitas, pengujian homogenitas, dan pengujian hipotesis.

\section{Hasil Penelitian dan Pembahasan}

Sebelum melakukan pembelajaran terlebih dahulu dilakukan pretest yang diuji untuk mengetahui kemampuan awal dari siswa. Soal pretest yang diberikan kepada siswa merupakan materi prasyarat untuk masuk kepada materi aturan sinus dan cosinus. Materi untuk soal pretest adalah teorema phytagoras. Siswa kelas X MIA 6 (pembelajaran problem posing) berjumlah 40 orang dan siswa kelas $\mathrm{X}$ MIA 5 (pembelajaran konvensional) berjumlah 40 orang. Hasil rata-rata skor pretest kelas experiment adalah 18,81 dan hasil rata-rata skor pretest kelas kontrol adalah 16,34.

Setelah dilakukan pretest pada kedua kelas, maka kedua kelas diberikan perlakuan yaitu kelas experiment diberikan perlakuan dengan model pembelajaran problem posing dan kelas kontrol dengan model pembelajaran konvensional. Setelah kedua kelas diberi perlakuan yang berbeda maka dilakukan postest untuk mengetahui kemampuan komunikasi matematis siswa. Soal yang diberikan adalah soal berbentuk isian yang berjumlah 9 butir soal. Sebelum soal tersebut diberikan, terlebih dahulu soal diuji cobakan di kelas XI MIA 6, untuk mengukur kelayakan soal seperti validitas, reliabilitas, daya pembeda, dan indeks kesukaran soal dan hasilnya dari 18 soal yang diberikan yang valid berjumlah 9 soal, dan mempunyai reliabilitas 0,472 dengan interpretasi sedang, sehingga soal layak untuk dipakai.

Dari hasil postest diperoleh rata-rata skor postest kelas experiment dengan model pembelajaran problem posing adalah 27,72 dan rata-rata skor postest kelas kontrol dengan model pembelajaran konvensional adalah 22,60.

Jumlah siswa pada kelas experiment yang memiliki $\mathrm{N}$-Gain tinggi sebanyak 10 siswa ataupun $25 \%$, jumlah siswa pada kelas experiment yang memiliki N-Gain sedang sebanyak 23 siswa ataupun $57,5 \%$, dan jumlah siswa pada kelas experiment yang memiliki NGain rendah sebanyak 7 siswa 17,5\%, sedangkan jumlah siswa pada kelas kontrol yang memiliki $\mathrm{N}$-Gain tinggi sebanyak 6 siswa ataupun 15\%, jumlah

Echo Genesis Perangin-Angin, Humuntal Banjarnahor. Pengaruh Model Pembelajaran Problem Posing Berbantuan Scaffolding Terhadap Kemampuan Komunikasi Matematis Siswa Kelas X SMA Negeri 1 Lubuk Pakam. Jurnal Inspiratif, Vol. 3 No. 1 April 2017 
siswa pada kelas kontrol yang memiliki $\mathrm{N}$-Gain sedang sebanyak 13 siswa ataupun $32,5 \%$, dan jumlah siswa pada kelas kontrol yang memiliki N-Gain rendah sebanyak 21 siswa 52,5\%.

Terlebih dahulu akan diuji dua rata-rata skor kelas experiment dan kelas kontrol untuk melihat apakah kemampuan awal kedua kelas sama ataupun berbeda. Adapun uji yang digunakan adalah uji statistik $t$ dua pihak, pada lampiran 36 diperoleh hasil $t_{\text {hitung }}=2,193$ dan $t_{\text {tabel }}$ dengan $\mathrm{dk}=40+40-2=78$ dan $\alpha=$ 0,05 adalah $t_{\text {tabel }}=1,994$. Berdasarkan perhitungan pada lampiran 36 diperoleh $t_{\text {hitung }}=2,193$, tidak berada dalam interval $-1,994<t<1,994$. Sehingga $\mathrm{H}_{0}$ ditolak dan $\mathrm{H}_{a}$ diterima. Sehingga dapat disimpulkan bahwa rata-rata tes kemampuan awal kedua kelas berbeda. Karena rata-rata skor kemampuan awal (pretest) kedua kelas berbeda, data yang digunakan untuk uji normalitas, uji homogenitas, dan uji hipotesis adalah data selisih postest dengan pretest (uji pihak kanan).

Salah satu persyaratan analisis yang harus dipenuhi sebelum melakukan uji statistik parametrik adalah sebaran data harus berdistribusi normal. Untuk mengetahui sebaran data berdistribusi normal atau tidak dapat dilakukan uji normalitas dengan menggunakan Uji ChiSquare dengan syarat normal yang harus dipenuhi adalah $\chi_{\text {hitung }}^{2}<\chi_{\text {tabel }}^{2}$ pada taraf $\alpha=0,05$. Data selisih postest dengan pretest dari kedua kelas sampel yaitu siswa yang belajar dengan model pembelajaran problem posing dan model pembelajaran konvensional memiliki sebaran data yang berdistribusi normal pada taraf signifikansi $\alpha=0,05$ dimana $\chi_{\text {hitung }}^{2}<\chi_{\text {tabel }}^{2}$. Pengujian homogenitas data selisih postest dengan pretest diuji menggunakan uji $\mathrm{F}$ yang bertujuan untuk mengetahui kehomogenan varians datadata kelompok sampel penelitian. Data masing-masing kelompok sampel dinyatakan memiliki varians yang homogen, apabila nilai $F_{\text {hitung }}<F_{\text {tabel }}$ pada taraf $\alpha=0,05$. Untuk data selisih postest dengan pretest kedua kelas sampel memiliki $F_{\text {hitung }}<F_{\text {tabel }}$. Sehingga data selisih postest dengan pretest kelompok siswa dengan model pembelajaran problem posing dan model konvensional memiliki varians yang homogen.

Selanjutnya dilakukan pengujian hipotesis untuk kemampuan komunikasi matematis dengan menggunakan uji-t. Setelah dilakukan pengujian data, ternyata diperoleh hasil pengujian kemampuan komunikasi matematis pada taraf $\alpha=0,05$ $t_{\text {hitung }}>t_{\text {tabel }}$ yaitu $3,121>1,667$, maka $\mathrm{H}_{0}$ ditolak dan $\mathrm{H}_{a}$ diterima, yang berarti kemampuan komunikasi matematis siswa yang diajar menggunakan model pembelajaran problem posing berbantuan scaffolding lebih tinggi daripada kemampuan komunikasi matematis siswa yang diajar tanpa menggunakan model pembelajaran problem posing berbantuan scaffolding. Untuk hasil proses penyelesaian masalah siswa dalam menyelesaikan pretest dan postest terhadap ketiga aspek komunirkasi matematis mengalami perbedaan pada setiap aspek. Pada aspek drawing, nilai rata-rata untuk pretest siswa dikelas experiment adalah 59,75 sedangkan dikelas kontrol 49,33. Pada aspek matematical expression, nilai rata-rata untuk pretest siswa dikelas experiment adalah 50,58 sedangkan dikelas kontrol 44,33. Pada aspek written text, nilairatarata untuk pretest siswa dikelas experiment adalah 46,41 sedangkan dikelas kontrol 42,5. Pada aspek drawing, nilai rata-rata untuk postest siswa dikelas experiment adalah 78,56 sedangkan dikelas kontrol 65,12. Pada aspek matematical expression, nilai rata-rata untuk postest siswa dikelas experimentadalah 77,5 sedangkan dikelas kontrol 61,75. Pada aspek written text,nilairata-rata untuk postest siswa dikelas experiment adalah 75,31 sedangkan dikelas kontrol 60,62.

Dapat disimpulkan bahwa siswa yang mendapatkan pembelajaran problem posing berbantuan scaffolding memiliki kemampuan komunikasi matematis pada setiap aspek yang lebih tinggi daripada siswa yang mendapat pembelajaran konvensional.

Echo Genesis Perangin-Angin, Humuntal Banjarnahor. Pengaruh Model Pembelajaran Problem Posing Berbantuan Scaffolding Terhadap Kemampuan Komunikasi Matematis Siswa Kelas X SMA Negeri 1 Lubuk Pakam. Jurnal Inspiratif, Vol. 3 No. 1 April 2017 


\section{Kesimpulan}

Berdasarkan hasil penelitian dan pengolahan data maka dapat ditarik kesimpulan sebagai berikut:

1. Kemampuan komunikasi matematis siswa kelas X SMA Negeri 1 Lubuk Pakam yang diajar menggunakan model pembelajaran problem posing berbantuan scaffolding lebih tinggi daripada kemampuan komunikasi matematis siswa kelas X SMA Negeri 1 Lubuk Pakam yang diajar tanpa menggunakan model pembelajaran problem posing berbantuan scaffolding sehingga "terdapat pengaruh model pembelajaran problem posing berbantuan scaffolding terhadap kemampuan komunikasi matematis siswa".

2. Peningkatan kemampuan komunikasi matematis siswa kelas $\mathrm{X}$ MIA 6 (Experiment) yang diajar menggunakan model pembelajaran problem posing berbantuan scaffolding lebih tinggi daripada peningkatan kemampuan komunikasi matematis siswa kelas X MIA 5 (Kontrol) yang diajar menggunakan model pembelajaran konvensional.

\section{Saran}

Berdasarkan hasil penelitian ini maka saran yang dapat peneliti berikan adalah:

1. Bagi guru matematika SMA dapat menggunakan model pembelajaran problem posing berbantuan scaffolding sebagai salah satu alternatif pembelajaran dalam upaya meningkatkan kemampuan komunikasi matematis siswa dalam proses pembelajaran sehingga siswa lebih mudah dan mampu dengan sendirinya memahami dan mempelajari materi yang diajarkan.

2. Bagi guru-guru atau peneliti yang akan menggunakan model pembelajaran problem posing berbantuan scaffolding sebaiknya lebih memperhatikan alokasi waktu yang ada agar seluruh tahapan-tahapan pembelajaran dapat dikerjakan dengan baik sehigga diperoleh hasil yang memuaskan.

\section{DAFTAR PUSTAKA}

Abdurrahman, Mulyono. 2012. Anak Berkesulitan Belajar: Teori, Diagnosis, dan Remediasinya. Jakarta : Rineka Cipta.

Anghileri, Juliana. 2006. Scaffolding Practice that Enhace Mathematics Learning. Journal Of Mathematics Teacher Education, 9(1):33-52. (diakses 10 Januari 2017 10:28)

Ansari, Bansu. 2009. Komunikasi Matematik:Konsep dan Aplikasi. Banda Aceh : Pena.

Arifin, Zaenal. 2009. Evaluasi Pembelajaran. Bandung : PT Remaja Rosdakarya.

Arikunto, Suharsimi. 2006. Prosedur Penelitian Suatu Pendekatan Praktik. Jakarta : Rineka Cipta.

Elida, N. 2012. Jurnal Ilmiah Program Studi STKIP Siliwangi Bandung, Meningkatkan Kemampuan Komunikasi Matematik Siswa Sekolah Menengah Pertama Melalui Pembelajaran Think-TalkWrite (TTW). Vol 1, No.2: 178-185 (ejournal.stkipsiliwangi.ac.id/index.p hpinfinityarticleview1716), diakses 10 Januari 2017 10:22)

Fachrurazi. 2011. Penerapan Pembelajaran Berbasis Masalah Untuk Meningkatkan Kemampuan Berpikir Kritis dan Komunikasi Matematis Siswa Sekolah Dasar. Journal Edisi Khusus No.1: 76-89 ISSN 1412-566X.

(http://jurnal.upi.edu/file/8Fachrurazi.pdf, diakses 10 Januari 2017 10:24)

Fadilah, dkk. Kemampuan Komunikasi Matematis Siswa Sekolah Menengah Pertama dan Madrasah Tsanawiyah Pada Materi Fungsi di

Echo Genesis Perangin-Angin, Humuntal Banjarnahor. Pengaruh Model Pembelajaran Problem Posing Berbantuan Scaffolding Terhadap Kemampuan Komunikasi Matematis Siswa Kelas X SMA Negeri 1 Lubuk Pakam. Jurnal Inspiratif, Vol. 3 No. 1 April 2017 
P.Brandan Kabupaten Langkat. Jurnal Pendidikan Matematika PARADIKMA. Vol 5, Nomor 2: 117-127

(digilib.unimed.ac.id/.../UNIMED-

Article-25813-Jurnal\%20117-

127.pdf diakses 10 Januari 2017 10:27)

Huda, Miftahul. 2014. Model-Model Pengajaran dan Pembelajaran. Yogyakarta : Pustaka Pelajar.

Kadir, Abdul, dkk. 2014. Dasar-Dasar Pendidikan. Jakarta : Kencana Prenamedia Grup.

Lestari, E.K., Yudhanegara, R.M. 2015. Penelitian Pendidikan Matematika. Bandung : PT.Refika Aditama.

Mahmudi, Ali. 2009. Komunikasi dalam Pembelajaran Matematika. Jurnal MIPMIPA UNHALU. Volume 8, Nomor 1: 1-9 (diakses 10 Januari 2017 10:44)

Panjaitan, Immanuel. 2015. Perbedaan Kemampuan Komunikasi Matematis Siswa yang Diajar dengan Pembelajaran Kooperatif Tipe Jigsaw dan Tipe TPS Pada Pokok Bahasan Trigonometri di Kelas $X$ SMA Negeri 1 Sidamananik. Skripsi tidak diterbitkan. Medan: Universitas Negeri Medan.

Pujiastuti, Emi. 2002. Pemanfaatan Model-Model Pembelajaran Matematika Sekolah sebagai Konsekuensi Logis Otonomi Daerah Bidang Pendidikan. Jurnal Matematika Komputer. Volume 5, Nomor 3: 146-155 (diakses 10 Januari 2017 10:48)

Readora, Putri. 2015. Perbedaan Pengaruh Model Pembelajaran Kooperatif Tipe Think Talk Write dan Pembelajaran Langsung Terhadap Kemampuan Komunikasi Matematik Siswa Kelas VIII SMP Negeri 1 Lubuk Pakam. Skripsi tidak diterbitkan. Medan: Universitas Negeri Medan.
Sagala, S. 2009. Konsep dan Makna Pembelajaran. Bandung : Alfabeta.

Saputra, H. 2012. Peningkatan Kemampuan Komunikasi Matematik Siswa Melalui Model Pembelajaran Kooperatif Tipe Think Talk Write. Jurnal Saina Riset . Volume 3, No.1: 1-5 (ejournal.unigha.ac.id/data/Journal $\% 20 \% 20$ SAINS\%20Riset $\% 20 \mathrm{vol} \%$ 203\%20no\&2094.pdf diakses 10 Januari 2017 12:00)

Septiani, D.W., Pembentukan Karakter dan Komunikasi Matematika melalui Model Problem Posing Berbantuan Scaffolding Materi Segitiga Kelas VII. Skripsi tidak diterbitkan. Semarang: Universitas Negeri Semarang.

Siregar, E., Nara, H. 2010. Teori Belajar dan Pembelajaran. Bogor : Ghalia Indonesia.

Sudjana. 2014. Metode Statistika. Bandung : Tarsito.

Sugiyono. 2012. Metode Penelitian Kuantitatif Kualitatif dan $R \& D$. Bandung : Alfabeta.

Sumiati dan Asra. 2016. Metode Pembelajaran. Bandung : CV.Wacana Prima.

Trianto. 2016. Mendesain Model Pembelajaran Inovatif-Progresif. Jakarta : Kencana Prenada Media Group.

Echo Genesis Perangin-Angin, Humuntal Banjarnahor. Pengaruh Model Pembelajaran Problem Posing Berbantuan Scaffolding Terhadap Kemampuan Komunikasi Matematis Siswa Kelas X SMA Negeri 1 Lubuk Pakam. Jurnal Inspiratif, Vol. 3 No. 1 April 2017 